\title{
Value Chain Analysis of Orange Commodity in the Bantama Market, Kumasi, Ghana
}

\author{
Jiah Sayson \\ Sanu Jacob \\ Wawan Sujarwo \\ Soleman Imbiri \\ Dewi Saraswati \\ Winfred Nazziwa \\ Corresponding email
}

\author{
Kindernothilfe e.V., Duisburg, Germany \\ Food Safety and Standards Authority of India, Ministry of \\ Health and Family Welfare, New Delhi, India \\ Ethnobiology Research Group, Research Centre for Biology, \\ Indonesian Institute of Sciences, Cibinong, Indonesia \\ Agribusiness Study Program, the University of Papua, \\ Manokwari, Indonesia \\ Development and Planning Board of Fakfak Regency, Fakfak, \\ Indonesia \\ National Youth Empowerment Network, Kampala, Uganda
}

\begin{abstract}
The performance of the local sub-sector of orange in Bantama, Kumasi should be improved. This study aims to improve the performance of the local orange value chain in the Bantama market using rich picture analysis, scenario analysis, cigar box analysis, stakeholders' analysis, and SWOT analysis. The study suggests two strategic objectives, (1) the Bantama orange traders association (BOTA) coped with lack of storage facilities, which is expected that BOTA is linked directly to at least three major orange processors in Bantama by conducting stakeholders meeting between BOTA and orange processors, and a memorandum of understanding between BOTA and orange processors; (2) the local government promoted the orange industry of Bantama, which is expected that BOTA advocated to the local government for the establishment of market storage facility by preparing advocating plan by BOTA, and consultation meetings with local government.
\end{abstract}

Keywords: Cigar box analysis, local product, rich picture analysis, scenario analysis, stakeholder analysis, SWOT analysis, traditional market

\section{INTRODUCTION}

The value chain includes all the activities that are undertaken in transforming raw materials into a product that is sold and consumed. These include the direct functions of primary production, collection, processing, wholesaling and retailing, as well as the support functions, such as input supply, financial services, transport, packaging and advertising. This study is a value chain analysis of the orange commodity in the Bantama Market of Kumasi. The analysis is limited to the chain functions of collection, processing, wholesaling, and retailing and less on primary production. The limitation is the time spent for the field visit, otherwise the analysis tried to capture all available information from the wider chain functions (Vermeulen et al., 2008). 


\section{METHODS}

\section{Study Area}

The Bantama Orange Traders Association (BOTA) in Kumasi, Ghana specializes in mango and orange, but the market activity for the latter is relatively more dynamic. This led to the choice of orange as the primary commodity for this study. Bantama Orange Traders Association is a small group of 30 women wholesaler-buyer-traders. Membership is decided by the market queen. The 30 stalls of tropical fruits occupy for free the land owned by the traditional chief of Bantama. This is the second location after they were driven away from the previous one. The administration fund is sourced from an entry fee of 15 cedi and monthly membership fee of 5 cedi. There is no insurance fund. The total fund is very small such that they do not utilize this for productive activities but only for welfare like contributing to the wedding and funeral costs of individual members and their families. The individual member pays a rental fee of 50 cedi/per truck entry to the local government. The market activity is from Monday to Saturday starting at 5 am and closing at $6 \mathrm{pm}$. The market queen takes charge of the activities 6 days a week. She settles disputes between and among traders. The participation of men in the market is in transport and carriage. Some are big middlemen.

\section{Data Collection}

The study starts with a rich picture of the value chain (Avison et al., 1992). Each of the important chain function was described and analyzed. The drivers, trends, and issues affecting the value chain and its actors were identified and used to explore future scenarios (Hassani, 2006). The information gathered for this study are from interviews conducted with the members of the Bantama Orange Traders Association and the owner of the processing company E-Juice Business. The discussion during the chain-wide learning workshop with the experts in the value chain functions was very helpful.

\section{Data Analysis}

The analysis is complemented by a sophisticated profit analysis tool called the Cigar Box Method (van Lieshout, 2016). It uses the formula Profit $=($ Profit - Variable Cost $) *$ quantity sold - Fixed Cost or contribution minus fixed cost is profit. This is different from the traditional formula of total revenue minus total cost is profit. This method entails a detailed collection of information, so that one can decide at the end how to adjust and reduce the costs and increase capacity utilization to gain maximum profit. A stakeholder analysis was done to see who are the institutions and actors most likely to involve and resist in important changes (Fletcher et al., 2003). Finally, strategies for policy development were developed through SWOT Analysis (Hill and Westbrook, 1997). 


\section{RESULTS AND DISCUSSION}

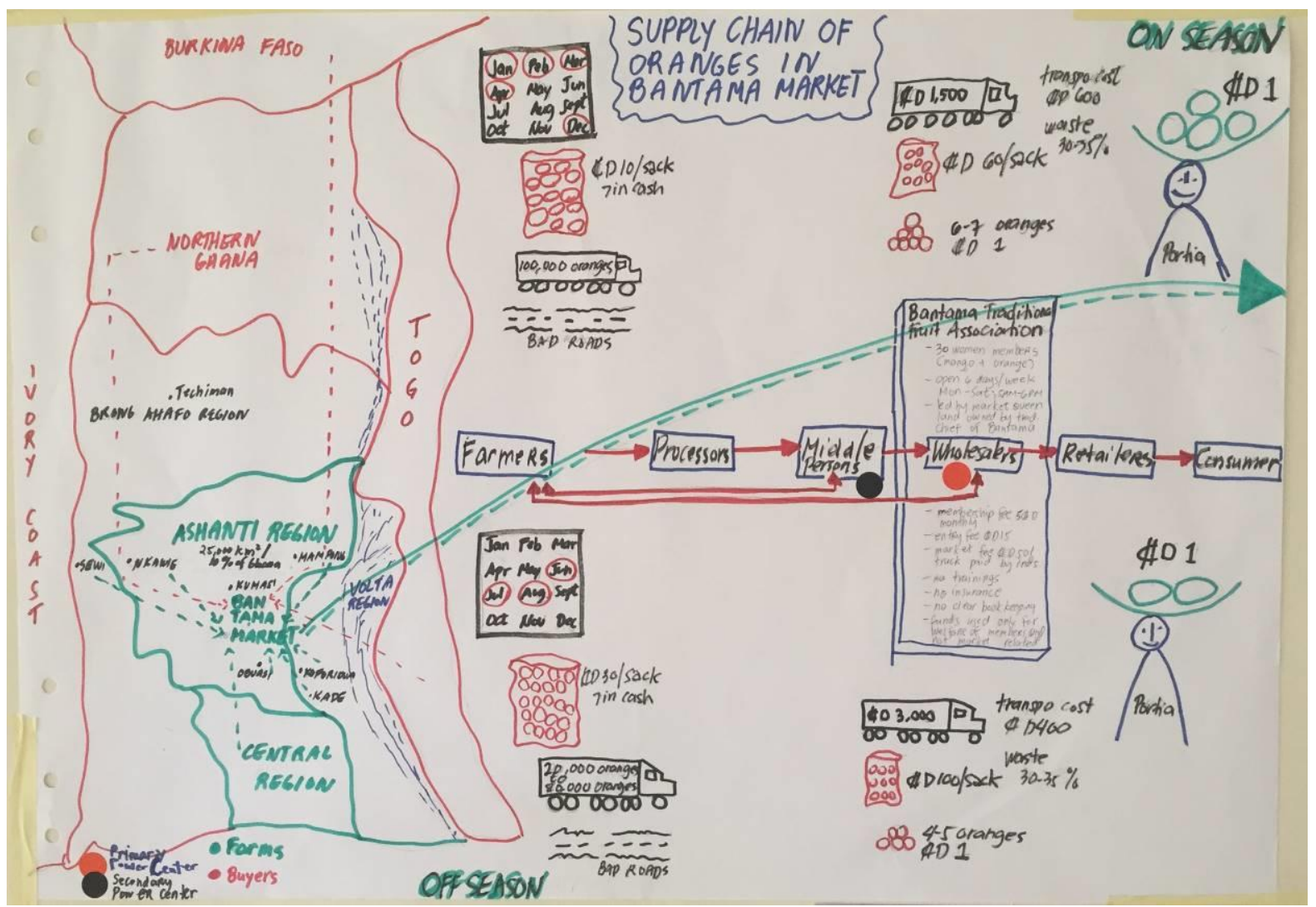

Figure 1. Rich picture of the orange supply chain

\section{The Season: Harvest and Spoils}

The peak season for orange lasts for five months from December to April. This is a period of abundance in the Ashanti region of Ghana and very efficient for the buyers who do not need to hire and send trucks to get oranges outside the region. Each hired truck is paid at 1500 cedi ( 1 USD $=4.30$ Ghanaian Cedi). Overall, the transportation cost is less. It is estimated that a single truck could load sacks of 100,000 oranges. Each sack is bought from the farmer at 10 cedi. This is then sold by the traders at a wholesale price of 40 cedi/sack. For retail, this is sold at 1 cedi for 6-7 oranges.

The off season lasts for three months from June to August. This period increases transaction costs for communication and transportation. Oranges are sourced as far as the Central region of Ghana. Each hired truck is paid at 3,000 cedi. A single truck loads sacks of 20,000-80,000 oranges, where each sack is bought at 30 cedi. Less supply and competition from buyers outside Ghana (Burkina Faso, Ivory Coast, and Tongo) expectedly raises the cost of the commodity. Traders then sell the oranges at a wholesale price of 100 cedi/sack. For retail, this is sold at 1 cedi for only 4-5 oranges.

The transaction both for peak and off season, is always in cash. Farmers do not get any advance payment or security deposit from the buyers. Buyers claim that the price of the orange is determined by the farmers. The high demand inside and outside Ghana makes this possible.

The technology in this chain is very traditional. At the farm, farmers do not spray the trees at the right time and cannot guarantee that they pick the oranges from its tree. Many 
trees are shaken to bring down the oranges. They drop to the floor injured and then fungal pathogens sets in. Unlike bananas and mangoes, oranges are non-climactic fruits so they are ready for picking when ripe. Dropping them to the floor during ripe stage invites spoilage. The bruised oranges are loaded into the trucks and easily rot when brought to the market. There is no storage facility. Farmers call the buyers when the oranges are ripened and hope that the trucks arrive soon.

The harvesting technology is as traditional as the packaging and transportation of the orange. These are loaded in sacks not on crates, without individual packaging nor waxing to prevent injury, and squeezed in a sack in a huge pile. The oranges travel in bad roads and engulfed in heat as they are transported for long hours in an open truck. As they reach the Bantama market, they are dumped and displayed in damp stalls without floor cover. The harvesting and storage practice and technology make a good combination for a huge volume of orange spoilage. For both peak and off season the spoilage is at a minimum estimate of 30$35 \%$, borne by the buyer. For the off season, most of the losses are borne by the farmers who do not practice weeding in the farm. At the processing sector, there is one local and small juicing company in the whole of Ghana, while the rest are multinationals.

The spoilage is high, but the buyers compensate this by not adding any other tropical fruit in their stock. They do not transfer the spoilage loss to the retailers. Do they still profit? The buyers think this commodity is profitable. Almost all the members of the BOTA have been in the market for 20 years. They never thought of juicing the ripe oranges so that they preserve these and reduce the loss. They throw these in the garbage dump.

\section{Retailing Orange}

An orange retailer, like Portia, is usually a woman who walks and balances about 20 $\mathrm{kg}$ of oranges on top of her head. Selling all oranges in one day is a good day and selling all in two days is a bad day for a retailer. She earns 20 cedi per day; when she is sick she earns nothing. She estimates that $10 \%$ of one batch of oranges sold per day gets spoiled. Unlike the farmers and traders, the retailer sells the oranges at a fixed price of one cedi for four oranges for peak season and one cedi for two oranges for off season. She faces no competition from other retailers. She has loyal customers whom she visits regularly. She has a good relationship with the women traders, she comes to the market daily, and can pick the oranges that she wants to retail. She says orange retail is profitable for her; she has been retailing for 10 years. Over the years, she has sold the same oranges to the same people. She has developed simple presentation like peeling the oranges in an appealing way to the customers. She lets her customer choose their oranges, too.

\section{Processing Oranges and Cigar Box Analysis}

The $25 \%$ of the 55,000 ton/year of oranges in Ghana come from the Bantama market. How much of the $25 \%$ is processed? This is a problematic question because processing in Ghana is mainly for pineapple and mangoes, not oranges. There are no enablers for this sector. There could be a big market for processed oranges, but there are no machines in Ghana for this. Even the big Blueskies processing company in Ghana is processing other fruits except oranges.

A small-scale Ghanaian E-JUICE Business takes on the challenge. It is a backyard family-owned and run company that processes five different tropical fruits: mangoes, pineapples, papaya, passion fruit, and oranges. Sometimes, they also process watermelons. The processing is simple: they juice the fruits and bottle them fresh. 
The peak season for processing oranges is in sync with the harvesting and trading season. This peaks from December to February. This goes down from March to May then picks up again from July to November. The prospects for this neophyte juice business is good. The Cigar Box Analysis of the processing company shows a profitability of $27 \%$ with a capacity utilization of only $27 \%$. To increase capacity utilization, the company needs to add juicing machines and increase production from the usual five hours. Adding lime to the juice can also decrease the $\mathrm{PH}$ level of the juice and increase its shelf life.

\begin{tabular}{|c|c|c|c|c|c|}
\hline \multirow{2}{*}{\multicolumn{3}{|c|}{$\begin{array}{l}\text { TROPICAL FRUIT, E-JUICE, KUN } \\
\text { Fresh Orange Juice, packed in } 330 \mathrm{ml} \text { bottle }\end{array}$}} & \multirow{2}{*}{\multicolumn{3}{|c|}{ Jun-16 }} \\
\hline & & & & & \\
\hline \multirow{5}{*}{$\begin{array}{l}\text { Price (delivered customer) } \\
\text { VC4 Sales commission paid } \\
\text { VC4 transport to client paid } \\
\text { Price (EXW) }\end{array}$} & \multicolumn{2}{|l|}{$\begin{array}{c}\text { Cedi } \\
\text { per liter }\end{array}$} & \multirow{5}{*}{$\begin{array}{l}\text { Total Revenue (Delivered) } \\
\text { Total Cost } \\
\text { Profit Before Tax } \\
\text { Profitability \% } \\
\end{array}$} & \multicolumn{2}{|l|}{$\begin{array}{c}\text { Cedi } \\
\text { per year }\end{array}$} \\
\hline & 9.1 & $100 \%$ & & \multicolumn{2}{|l|}{136,364} \\
\hline & 0.9 & $10 \%$ & & \multicolumn{2}{|l|}{100,190} \\
\hline & 0.6 & $7 \%$ & & \multicolumn{2}{|l|}{36,173} \\
\hline & 7.6 & $83 \%$ & & \multicolumn{2}{|l|}{$27 \%$} \\
\hline \multirow{4}{*}{$\begin{array}{l}\text { Price (delivered factory) per kg } \\
\text { Processing ratio } \\
\text { Raw Material cost } \\
\text { Other ingredients }\end{array}$} & 0.80 & & \multirow{2}{*}{$\begin{array}{l}\text { Asset value (+stocks of goods) } \\
\text { Depreciation \% }\end{array}$} & 103,000 & \multirow{4}{*}{$10 \%$} \\
\hline & 1.52 & & & $6.5 \%$ & \\
\hline & 1.21 & $28 \%$ & \multirow[t]{2}{*}{ FC1 } & \multirow[t]{2}{*}{6,695} & \\
\hline & 0.0 & $0 \%$ & & & \\
\hline \multirow[t]{2}{*}{ VC1 } & \multirow[t]{2}{*}{1.2} & \multirow[t]{2}{*}{$28 \%$} & \multirow{2}{*}{$\begin{array}{l}\text { Debt (loan for assets/working capital) } \\
\text { Interest rate }\end{array}$} & - & \multirow{4}{*}{$0 \%$} \\
\hline & & & & $0.0 \%$ & \\
\hline \multirow{2}{*}{$\begin{array}{l}\text { Processing cost (washing, grading, destemming) } \\
\text { Energy cost (electricity, diesel, fuelwood) }\end{array}$} & - & & \multirow[t]{2}{*}{ FC2 } & \multirow[t]{2}{*}{-} & \\
\hline & 0.30 & & & & \\
\hline \multirow[t]{2}{*}{$\mathrm{VC} 2$} & 0.3 & $7 \%$ & Number of FTE employed & 4 & \multirow{4}{*}{$\begin{array}{l}89 \% \\
1 \% \\
90 \%\end{array}$} \\
\hline & & & $\begin{array}{l}\text { Salaries staff incl. social taxes } \\
\text { Other overhead, rent, internal revenue tax }\end{array}$ & $\frac{60,000}{600}$ & \\
\hline Cost of packing of selling unit & 0.91 & & \multirow{2}{*}{ FC3 } & \multirow[t]{2}{*}{60,600} & \\
\hline Number of selling units per liter & 3.03 & & & & \\
\hline VC3 & 2.8 & $65 \%$ & FC & 67,295 & $100 \%$ \\
\hline \multirow{2}{*}{$\begin{array}{l}\text { Overall losses, returned unsold product } \\
\text { VC }\end{array}$} & - & $0.0 \%$ & \multirow{2}{*}{$\begin{array}{l}\text { FC \% attributed to product } \\
\text { FC (attributed to product) }\end{array}$} & \multirow{2}{*}{$\begin{aligned} 20 \% \\
13,459 \\
\end{aligned}$} & \\
\hline & 4.3 & $100 \%$ & & & \\
\hline & 3.3 & & Quantity sold q (liters/year) & 15,000 & \\
\hline Margin \% of Price (EXW) & $44 \%$ & & Contribution & 49,632 & \\
\hline vc & 4.3 & $83 \%$ & Break even volume (sales) & 4,068 & \\
\hline & & & Break even volume (raw material) & 6,163 & \\
\hline Fixed Cost / q & 0.9 & $17 \%$ & & & \\
\hline & & & Output capacity per hour in liters & 10 & \\
\hline Total Cost / q & 5.2 & $100 \%$ & Production hours per day & 22 & \\
\hline & & & Length of production season in days & 250 & \\
\hline Profit / q & 2.4 & & Maximum capacity per year & 55,000 & \\
\hline & & & Capacity utilization & $27 \%$ & \\
\hline
\end{tabular}

Figure 2. Cigar box analysis

\section{Insights}

The field observations and analysis were shared by the team of researchers to the experts in the value chain function groups. Representatives from the traders, wholesalers, middlemen, retailers, farmers, processors, and local government were invited for a 1-day Chain Wide Learning Workshop. This was organized at the Center for Innovative Learning, Kwame Nkrumah University of Science and Technology, Kumasi, Ghana on June 27, 2016. The collective feedback and suggestions for improvement of each chain function are summarized here.

For the farmers, there is need to encourage them to pick oranges from the tree. For this, there could be incentives provided by the buyers. Training is important to sensitize farmers to spray fertilizers at the right time and help them to wax the oranges to protect 
against spoilage. For the wholesalers, it is important to organize storage facilities in the market. The Bantama Orange Traders Association could also benefit from management training. The urgent training is on bookkeeping. For the processors, there is clearly a demand for technology training and funding for business expansion. This can be lobbied to government and universities. Sensitization is needed for processors to appreciate other ways to process oranges like producing marmalade, pickles, and pectin extraction. For the government, there is high demand for better farm to market roads, provision of training, mentoring, and financing to the various chain functions, establishing physical infrastructures like proper shed and cold storage for the fruit commodities. For all the chain functions, reducing spoilage, which leads to garbage pile helps to promote better health and sanitation.

\section{Scenario Analysis: Mapping the Drivers, Trends, and Issues}

A mapping of the key drivers, trends, and issues affecting the value chain and its actors was done. The driving forces that cause change but are outside or external to the influential domain of the case and the trends or impact of the drivers at the case level are identified to plan for future scenarios. The driver is the cause and the trend is the effect. The trends can be certain or uncertain. Five drivers were identified and prioritized. Two critical uncertain but important trends were used for scenario analysis.

The scenario analysis was conducted to understand the wider environment and context of the orange supply chain, helping to stimulate and operationalize the planning process. The analysis starts by identifying the unit of analysis, which in this case is the Orange Supply Chain in the Bantama Market. The two uncertain but critical trends selected were demand for oranges and export level. This was plotted in the matrix of low and high scale. Four scenarios were created but the most likely scenario is the fourth one: increased price and buyers/consumers for substitute tropical fruits.

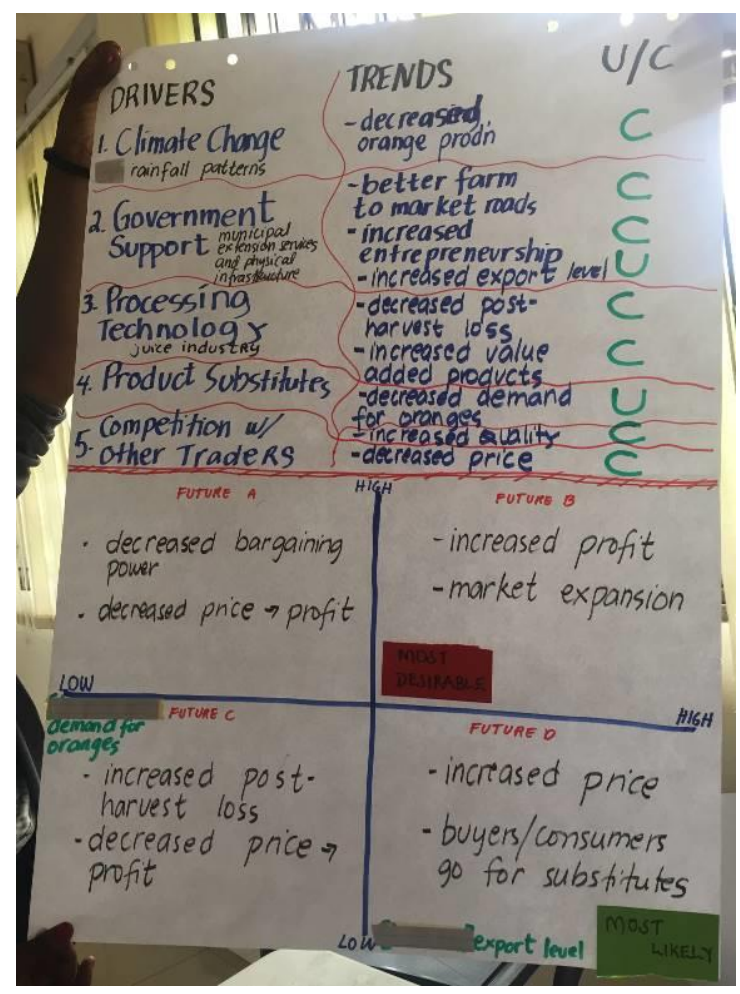

Figure 3. Scenario analysis 


\section{Stakeholder Analysis}

In developing a plan from the most likely scenarios, it is important to conduct a stakeholder analysis. This answers the important question of how should the most important and influential stakeholders participate and contribute to the realization of the plan.

Two tools are utilized in this process: the actor analysis matrix and the influenceimportance matrix. First, the eight most important stakeholders are identified as well as their primary task or activity. Their position in the decision-making system is analyzed. To what extent do they have a mandate, policy, knowledge, network or other power in relation to other actors in the case? The ranking starts from one as lowest and eight as highest. Their potential impact on the case is similarly ranked.

The second tool is the influence-importance matrix. The extent to which the stakeholder is able to persuade or coerce others into making decisions whether negative or positive is measured. Then, their importance is also weighed in terms of the priority in satisfying the stakeholders' needs and interests in the case.

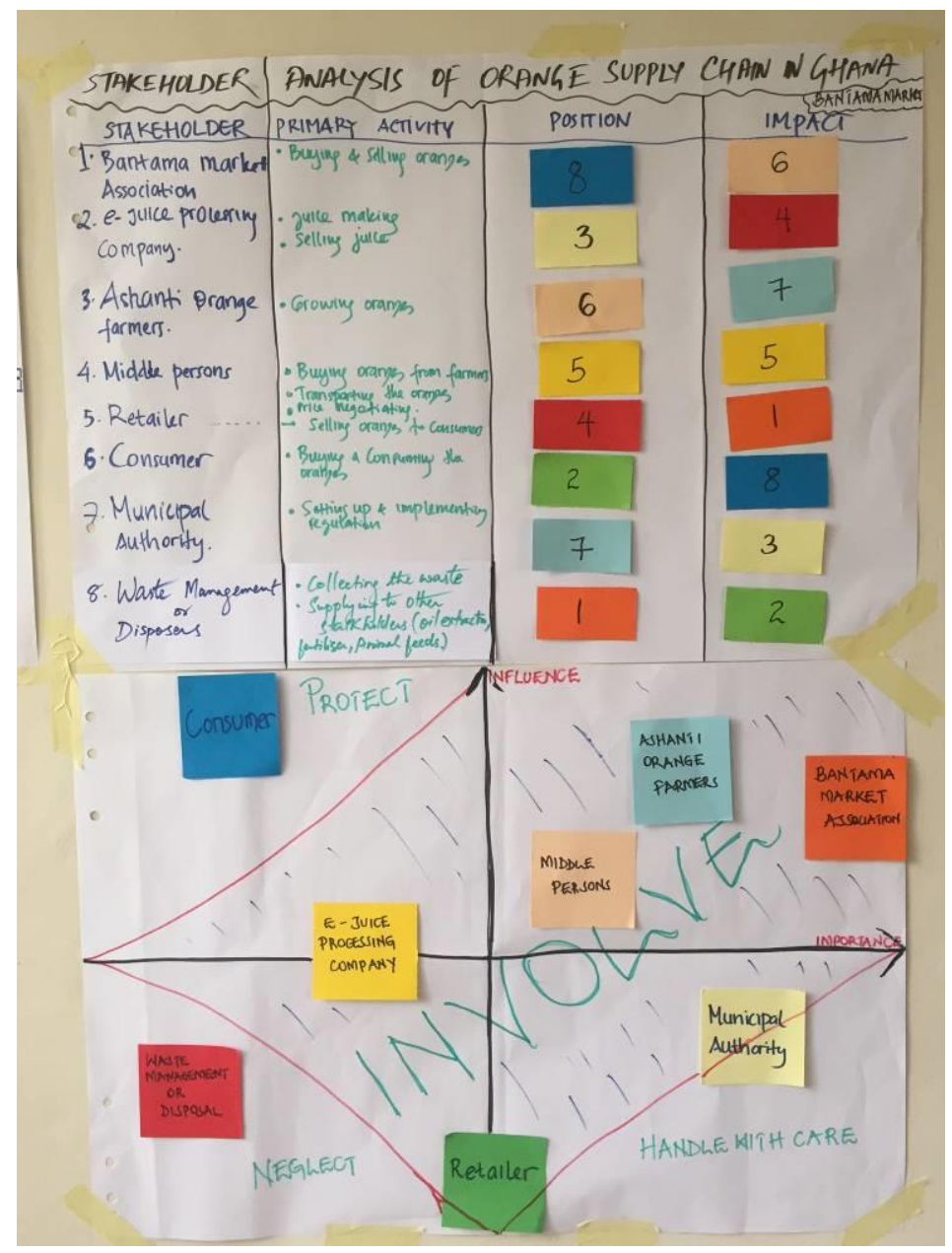

Figure 4. Stakeholder analysis

The result of the analysis showed that the flourishing of the orange supply chain in the Bantama Market needs a strong involvement of the Bantama Tropical Market Association, but also the Ashanti Orange Farmers who are not always active in chain wide discussions. The big issue of spoilage needs to be dealt with by these two groups, but a close connection with the processors can reduce spoilage by sending to them the oranges just in time before 
they rot and spoil. The Municipal Authority can encourage the processors by helping them raise capital for business research and development.

The household consumers need protection from increased price of oranges due to increased transaction costs. The retailers benefit from the efficiency of the farmers, traders, and processors. They will have a wide variety of commodities to sell. Portia, the retailer, can sell not just oranges but also jams, pickles, and other products. She need not bother about spoilage too. The waste management department of the municipality will have lesser workload from a less wasteful orange supply chain.

\section{Strategic Planning Process from SWOT to Strategic Options}

The strategic planning process is a step by step process of arriving at strategic options to improve the performance of the value chains. It is a participatory and reiterative process that builds on the experiences in every step taken. First, all the good and bad issues pertaining to the case were identified and discussed. The goodies were written in green cards and the baddies were written in the red cards. A total of 28 goodies and 32 baddies were identified. Second, we prioritized seven goodies and another seven baddies.

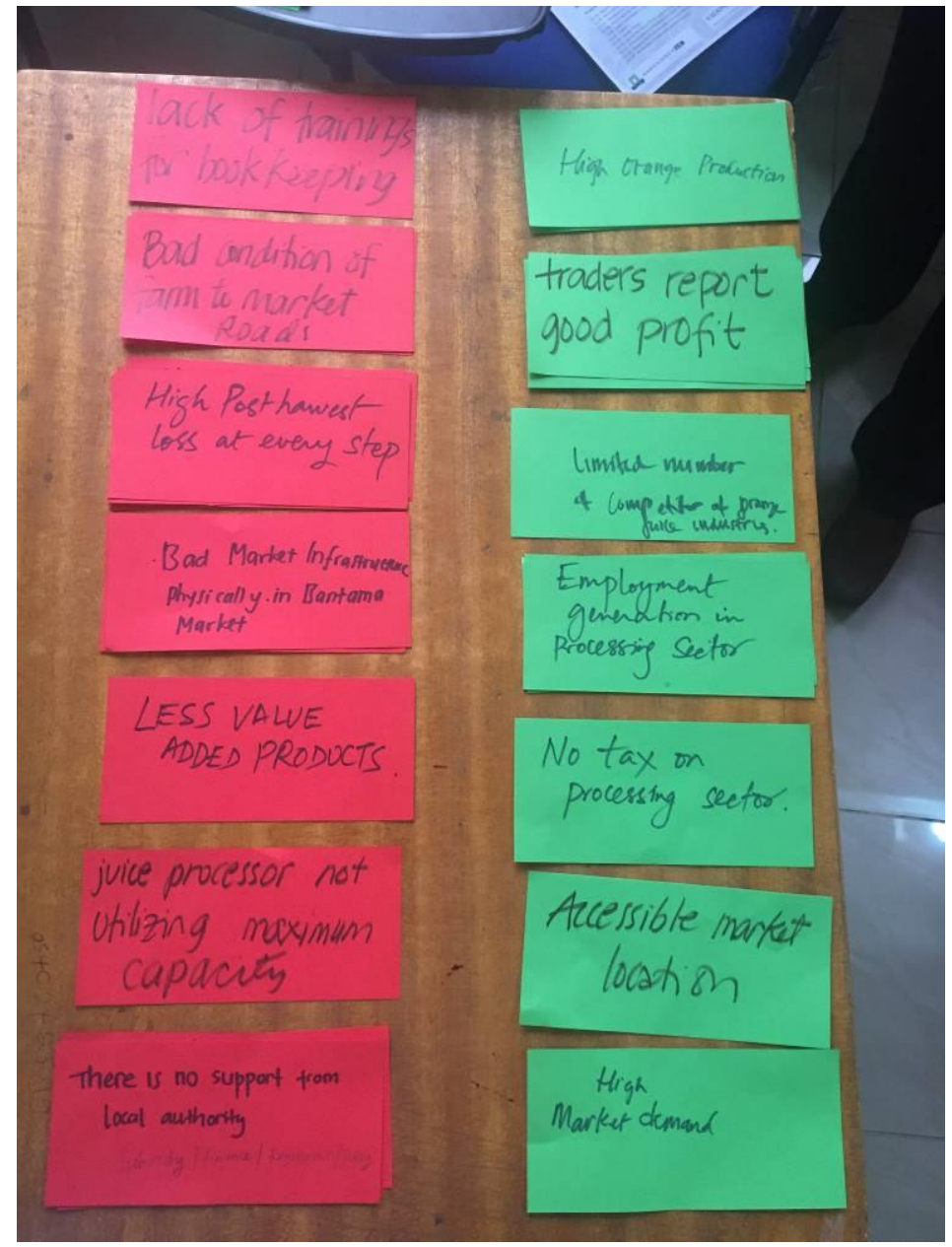

Figure 5. The good and bad issues

Third, we looked at the immediate cause that has created the goodies and the baddies. We decided the immediate cause is external or internal. The internal causes are written on yellow cards while the external causes were written on purple cards. Fourth, we rephrased 
each opportunity and threat into a positive statement. A SWOT matrix was built, i.e. Strength: goodie with an internal cause; Opportunity: goodie with an external cause; Threat: baddie with an external cause; Weakness: baddie with an internal cause. The strengths (three cards) and weaknesses (three cards) are lined up in rows and the opportunities (four cards) and threats (four cards) are lined up in columns.

Fifth, we assessed the relations in the matrix and marked the highest relations with five and lowest with one. The numbers were added for the strength and subtracted with the total for the weaknesses. The two highest numbers were then considered for the selection of the strategic options (SO). Sixth, we looked at the overall results and analyzed the entire matrix. The matrix was not too wide nor too tall, thereby ensuring that there is balance in considering the internal and external bias of the stakeholders.

Seventh, we looked at the strategic options and decided that we need to add another positive statement 'to be able to cope with lack of storage facilities for perishable product,' so that we can address the most likely scenario that prices are increased and buyers/consumers opt for alternative commodities. This scenario is caused largely by the high level of spoilage in the orange supply chain. We consider then this additional positive statement as the first strategic option. The second is 'to be able to take advantage of the fact that government wants to promote the processing industry.' This strategic option is very important so that the orange industry gets its needed support in funding and technology development.

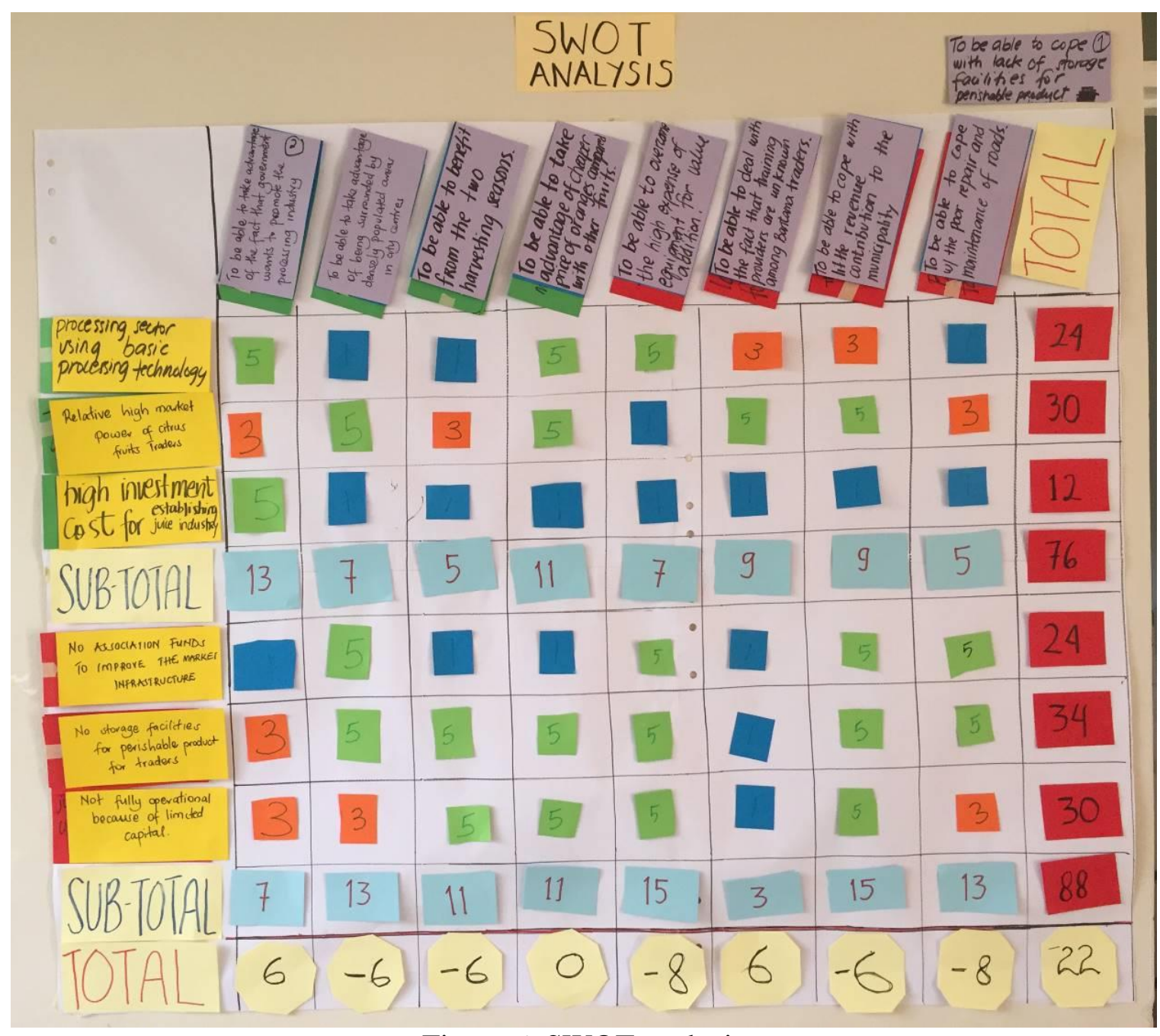

Figure 6. SWOT analysis 


\section{CONCLUSION}

The series of analytical tools applied in this chain value analysis resulted into a project proposal that aims to improve the performance of the local sub-sector of orange in Bantama, Kumasi. The strategic options selected are developed further by coming up result areas and major activities.

\section{ACKNOWLEDGEMENT}

The authors are grateful to the Bantama Orange Traders Association for sharing preliminary information about orange supply chain from farm to retail level. Special thanks to the resource staff of Wageningen University and Research, the Netherlands and Kwame Nkrumah University of Science and Technology, Kumasi, Ghana for providing guidance and facilities to complete this work successfully. The grant received under the Netherland Fellowship Programme (NFP) is duly acknowledged here.

\section{REFERENCES}

Avison, D.E., Golder, P.A. Shah, H.U. 1992. Towards an SSM toolkit: rich picture diagramming. European Journal of Information Systems 1(6): 397-408

Hassani, B.K. 2006. Scenario analysis in risk management: Theory and practice in finance. Springer International Publishing, Basel, Switzerland.

Hill, T., Westbrook, R. 1997. SWOT Analysis: It's time for a product recall. Long Range Planning 30(1): 46-52.

Fletcher, A., Guthrie, J., Steane, P., Roos, G., Pike, S. 2003. Mapping stakeholder perceptions for a third sector organization. Journal of Intellectual Capital 4(4): 505-527.

van Lieshout, O. 2016. Cigar Box Method®, Manual for the use of CB1: Cost price calculation made easy. www.globalfacts.nl

Vermeulen, S., Woodhill, J., Proctor, F.J. and Delnoye, R. 2008. Chain-wide learning for inclusive agrifood market development: a guide to multi-stakeholder processes for linking small-scale producers with modern markets. International Institute for Environment and Development, London, UK, and Wageningen University and Research Centre, Wageningen, the Netherlands. 